\author{
Marquette University \\ e-Publications@Marquette
}

10-20-2016

\title{
Synthesis, Structure and Antimicrobial Property of Green Composites from Cellulose, Wool, Hair and Chicken Feather
}

\author{
Chieu D. Tran \\ Marquette University, chieu.tran@marquette.edu \\ Franja Prosenc \\ University of Nova Gorica \\ Mladen Franko \\ University of Nova Gorica \\ Gerald Benzi \\ Marquette University
}

Follow this and additional works at: https://epublications.marquette.edu/chem_fac

Part of the Chemistry Commons

\section{Recommended Citation}

Tran, Chieu D.; Prosenc, Franja; Franko, Mladen; and Benzi, Gerald, "Synthesis, Structure and Antimicrobial Property of Green Composites from Cellulose, Wool, Hair and Chicken Feather" (2016). Chemistry Faculty Research and Publications. 529.

https://epublications.marquette.edu/chem_fac/529 


\title{
Synthesis, Structure and Antimicrobial Property of Green Composites from Cellulose, Wool, Hair and Chicken Feather
}

\author{
Chieu D. Tran \\ Department of Chemistry, Marquette University, \\ Milwaukee, WI \\ Franja Prosenc \\ Department of Chemistry, Marquette University, \\ Milwaukee, WI \\ Mladen Franko \\ Department of Chemistry, Marquette University, \\ Milwaukee, WI \\ Gerald Benzi \\ Department of Chemistry, Marquette University, \\ Milwaukee, WI
}




\begin{abstract}
Novel composites between cellulose (CEL) and keratin (KER) from three different sources (wool, hair and chicken feather) were successfully synthesized in a simple one-step process in which butylmethylimidazolium chloride $\left(\mathrm{BMIm}^{+} \mathrm{Cl}^{-}\right)$, an ionic liquid, was used as the sole solvent. The method is green and recyclable because $\left[\mathrm{BMIm}{ }^{+} \mathrm{Cl}^{-}\right]$used was recovered for reuse. Spectroscopy (FTIR, XRD) and imaging (SEM) results confirm that CEL and KER remain chemically intact and homogeneously distributed in the composites. KER retains some of its secondary structure in the composites. Interestingly, the minor differences in the structure of KER in wool, hair and feather produced pronounced differences in the conformation of their corresponding composites with wool has the highest a-helix content and feather has the lowest content. These results correlate well with mechanical and antimicrobial properties of the composites. Specifically, adding CEL into KER substantially improves mechanical strength of [CEL + KER] composites made from all three different sources, wool, hair and chicken feathers i.e., [CEL + wool], [CEL + hair] and [CEL + feather]. Since mechanical strength is due to $C E L$, and CEL has only random structure, [CEL + feather] has, expectedly, the strongest mechanical property because feather has the lowest content of a-helix. Conversely, [CEL + wool] composite has the weakest mechanical strength because wool has the highest a-helix content. All three composites exhibit antibacterial activity against methicillin resistant Staphylococcus aureus (MRSA). The antibacterial property is due not to CEL but to the protein and strongly depends on the type of the keratin, namely, the bactericidal effect is strongest for feather and weakest for wool. These results together with our previous finding that [CEL + KER] composites can control release of drug such as ciprofloxacin clearly indicate that these composites can potentially be used as wound dressing.
\end{abstract}

Keywords: Green, Ionic liquid, Keratin, Antibacteria, Wound dressing

\title{
1. Introduction
}

Sustainability, industrial ecology, eco-efficiency, and green chemistry are directing the development of the next generation of materials. Biodegradable and biocompatible materials generated from renewable biomass feedstock are regarded as promising materials that could replace synthetic polymers and reduce global dependence on fossil fuel sources. The most abundant biorenewable biopolymers on the earth include polysaccharide such as cellulose and keratin (wool, hair and chicken feather).

Keratins (KER) are a group of cysteine-rich fibrous proteins found such materials as wools, hairs, chicken feather, nails (Dullaart \& Mousquès, 2012). Of particular interest are hairs and chicken feathers as these materials are an important waste product from the salons and poultry industry but are generally left untreated because they have

Carbohydrate Polymers, Vol 151 (October 20, 2016): pg. 1269-1276. DOI. This article is (C Elsevier and permission has been granted for this version to appear in e-Publications@Marquette. Elsevier does not grant permission for this article to be further copied/distributed or hosted elsewhere without the express permission from Elsevier. 
limited solubility and cannot be easily and economically converted to environmentally benign products (Verma, Verma, \& Ray, 2008; Vilaplana, Stroemberg, \& Karlsson, 2010). Keratins are known to possess advantages for wound care, tissue reconstruction, cell seeding and diffusion, and drug delivery as topical or implantable biomaterial (Cui, Gong, Fan, Wang, Wang, Qiu; Hill, Brantley, \& Van Dyke, 2010; Justin, Saul, Ellenburg, de Guzman, \& Van Dyke, 2011; Vasconcelos \& Cavaco- Paulo, 2013). As implantable film, sheet, or scaffold, keratins can be absorbed by surrounding tissue to provide structural integrity within the body while maintaining stability under mechanical load, and in time can break down to leave neo-tissue (Cui et al., 2013, Hill et al., 2010, Justin et al., 2011 and Verma et al., 2008). The abundance and regeneration nature of wools, hairs and feathers coupled with the ability to be readily to be converted into biomaterials have made KER a subject of intense study (Justin et al., 2011 and Vilaplana et al., 2010).

Unfortunately, KER has relatively poor mechanical properties, and as a consequence, materials made from KER lack the stability required for medical applications (Cui et al., 2013, Hill et al., 2010, Sando et al., 2010 and Verma et al., 2008). To increase the structural strength of KER-based materials, attempts have been made to crosslink KER chains with a crosslinking agent or convert functional groups on its amino acid residues via chemical reaction(s) (Justin et al., $\underline{2011}$ and Sando et al., 2010). The rather complicated, costly and multistep process is not desirable as it may inadvertently alter its unique properties, making the KER-based materials less biocompatible and toxic, and removing or lessening its unique properties. A new method which can improve the structural strength of KER-based products not by chemical modification with synthetic chemicals and/or synthetic polymers but rather by use of naturally occurring polysaccharides such as CEL, is particularly needed.

We have demonstrated recently that a simple ionic liquid, butylmethylimmidazolium chloride $\left(\left[\mathrm{BMIm}{ }^{+} \mathrm{Cl}^{-}\right]\right)$, can dissolve polysaccharides such as CEL and chitosan (CS), and by use of this $\left[\mathrm{BMIm}{ }^{+} \mathrm{Cl}^{-}\right.$] as the sole solvent, we developed a simple, green and totally recyclable method to synthesize [CEL $+\mathrm{CS}$ ] composites just by dissolution without using any chemical modifications or reactions (Duri \& Tran, 2013; Harkins, Duri, Kloth, \& Tran, 2014; Mututuvari, Harkins, 
\& Tran, 2013; Mututuvari \& Tran, 2014; Tran, Duri, \& Harkins, 2013; Tran, Duri, Delneri, \& Franko, 2013). The [CEL + CS] composite obtained was found to be not only biodegradable and biocompatible but also retain unique properties of its components. Since $\left[\mathrm{BMIm}^{+} \mathrm{Cl}^{-}\right]$ can also dissolve wool keratin (Chen, Vongsanga, Wang, \& Byrne, 2014; Xie, Li, \& Zhang, 2005), it may be possible to use this IL as a solvent to synthesize composites containing CEL and keratin. In fact, Xie et al. have shown that wool keratin can be regenerated by initially dissolving in $\left[\mathrm{BMIm}^{+} \mathrm{Cl}^{-}\right]$and subsequently precipitated from methanol, and with this procedure, there were able to synthesize a $1 / 5$ wool keratin/cellulose composite (Xie et al., 2005). Recently, by using $\left[\mathrm{BMIm}{ }^{+} \mathrm{Cl}^{-}\right]$as a sole solvent we were able to synthesize composites from cellulose, chitosan and wool keratin with different compositions and concentrations (Tran \& Mututuvari, 2015). More importantly, we demonstrated that the composites can be used for drug delivery as the kinetics of the release can be controlled by adjusting the concentration of wool keratin in the composite (Mututuvari \& Tran, 2014).

Such consideration prompted us to initiate this study which aims to improve the mechanical properties of the KER-based composites by adding CEL to the composites, and to demonstrate that the composites will retain unique properties of their components. Since KER is known to have different structure and conformation depending on the source, (i.e., wool, hair or chicken feather) we synthesized [CEL + KER] composites with KER from either wool, hair or chicken feather Scheme 1. Various spectroscopic and imaging techniques including FTIR, powder X-ray diffraction, SEM and tensile strength were employed to characterize the composites and to determine their structure and property. Microbial assays were carried out to determine antimicrobial property of the composites, results obtained were correlated with the structure and conformation of the composites to formulate structureproperty relationship for the composites. The results of our initial investigation are reported herein.

Carbohydrate Polymers, Vol 151 (October 20, 2016): pg. 1269-1276. DOI. This article is @ Elsevier and permission has been granted for this version to appear in e-Publications@Marquette. Elsevier does not grant permission for this article to be further copied/distributed or hosted elsewhere without the express permission from Elsevier. 


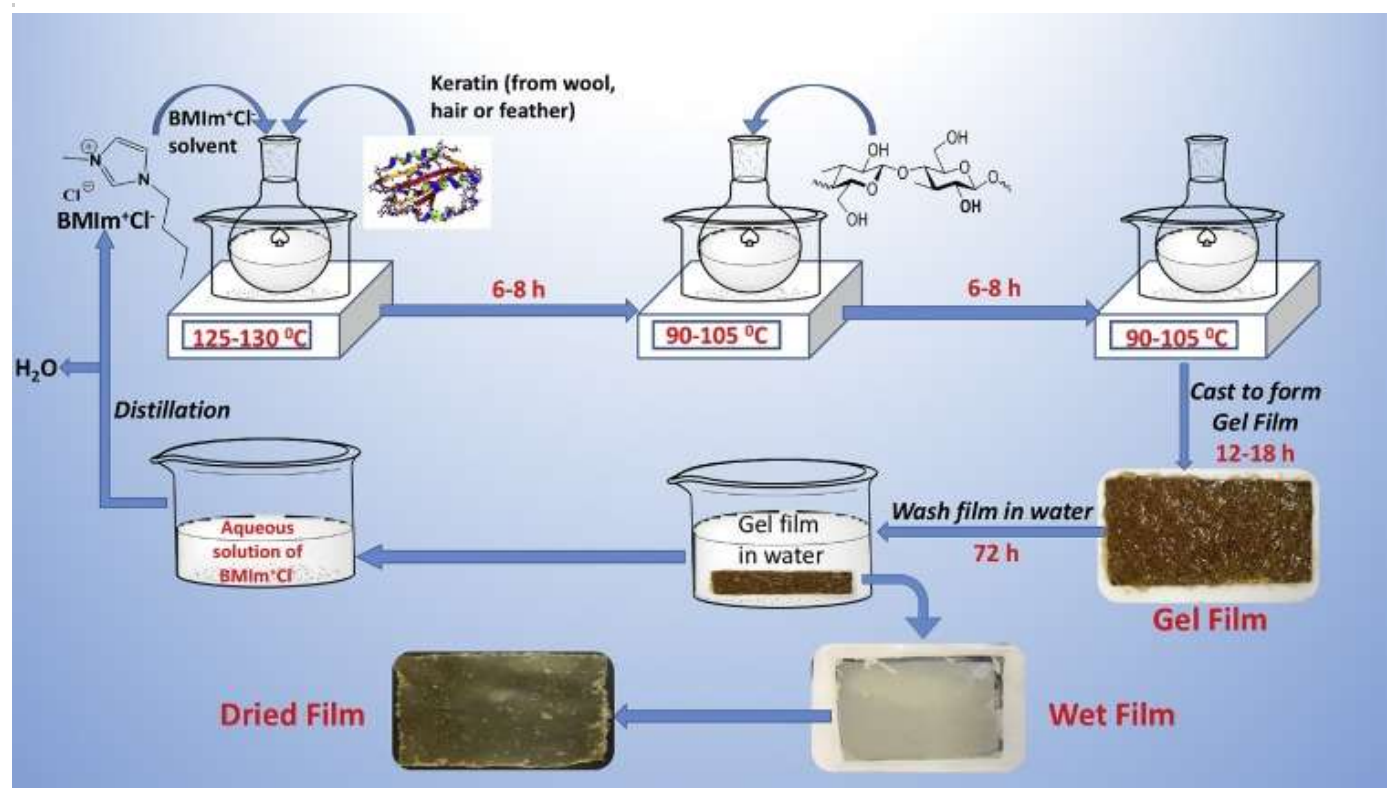

Scheme 1. Procedure used to prepare the $[C E L+C S+K E R]$ composite materials.

\section{Methods}

\subsection{Chemicals}

Microcrystalline cellulose $(D P \approx 300)$ were purchased from Sigma-Aldrich (Milwaukee, WI). Untreated hair from local saloons and chicken feathers from local poultry farms were washed with $0.5 \%$ SDS aqueous solution, rinsed with fresh water and air-dried, followed with additional cleaning by Soxhlet extraction with petroleum ether for $48 \mathrm{~h}$. Raw sheep wool (untreated), obtained from a local farm, was cleaned by Soxhlet extraction with a 1:1 acetone/ethanol mixture for $48 \mathrm{~h} .\left[\mathrm{BMIm}^{+} \mathrm{Cl}^{-}\right]$was prepared from freshly distilled 1 methylimidazole and $n$-chlorobutane (both from Alfa Aesar, Ward Hill, MA) using method previously reported ( Duri and Tran, 2013 and Haverhals et al., 2012).

\subsection{Instruments}

FTIR spectra from 450 to $4000 \mathrm{~cm}^{-1}$ were recorded on a Spectrum 100 Series FTIR spectrometer (Perkin Elmer, USA) at resolution of $2 \mathrm{~cm}^{-1}$ by the $\mathrm{KBr}$ method. Each spectrum was an average of 64 individual spectra. X-ray diffraction (XRD) 
measurements were taken on a Rigaku MiniFlex II diffractometer utilizing the $\mathrm{Ni}$ filtered $\mathrm{Cu}$ Ka radiation (1.54059 $\AA$ ). The voltage and current of the X-ray tube were $30 \mathrm{kV}$ and $15 \mathrm{~mA}$ respectively. The samples were measured within the $2 \theta$ angle range from 2.0 to 85 . The scan rate was 50 per minute. Data processing procedures were performed with the Jade 8 program package (Duri, Majoni, Hossenlopp, \& Tran, 2010). The surface and cross-sectional morphologies of the composite films were examined under vacuum with a JEOL JSM-6510LV/LGS Scanning Electron Microscope with standard secondary electron (SEI) and backscatter electron (BEI) detectors. Prior to SEM measurement, the film specimens were made conductive by applying a $20 \mathrm{~nm}$ gold-palladium-coating onto their surfaces using an Emitech K575x Peltier Cooled Sputter Coater (Emitech Products, TX). The tensile strength of the composite films were evaluated on an Instron 5500R tensile tester (Instron Corp., Canton, MA) equipped with a $1.0 \mathrm{kN}$ load cell and operated at a crosshead speed of $5 \mathrm{~mm} \mathrm{~min}^{-1}$. Each specimen had a gauge length and width of $25 \mathrm{~mm}$ and $10 \mathrm{~mm}$ respectively. Thermogravimetric analyses (TGA) (TG 209 F1, Netzsch) of the composite films were investigated at a heating rate of $10{ }^{\circ} \mathrm{C} \mathrm{min}-1$ from 30 to $600{ }^{\circ} \mathrm{C}$ under a continuous flow of $20 \mathrm{~mL} \mathrm{~min}^{-1}$ nitrogen gas.

\subsection{In vitro antibacterial assays}

Nutrient broth (NB) and nutrient agar (NA) were obtained from VWR (Radnor, PA). The bacterial cultures used in this study were obtained from the American Type Culture Collection (ATCC, Rockville, MD). Seven different composites with different compositions and concentrations were used. They were 40:60 Hair:CEL; 40:60 Feather:CEL, 65:35 Hair:CEL, 65:35 Feather:CEL, 80:20 Hair:CEL, 75:25 Feather:CEL and 90:10 Hair:CEL.

The composites were tested for antibacterial activity on model bacterial strains E. coli (ATCC 8739), Staphylococcus aureus (ATCC 25923), methicillin resistant $S$. aureus (ATCC 33591), vancomycin resistant Enterococcus faecalis (ATCC 51299), and Pseudomonas aeruginosa (ATCC 9027) using previously published protocol ( $\underline{\text { Harkins }}$ et al., 2014, Mututuvari et al., 2013 and Tran, Duri and Harkins, 2013).

Carbohydrate Polymers, Vol 151 (October 20, 2016): pg. 1269-1276. DOI. This article is (C) Elsevier and permission has been granted for this version to appear in e-Publications@Marquette. Elsevier does not grant permission for this article to be further copied/distributed or hosted elsewhere without the express permission from Elsevier. 
Preparation of the overnight bacterial culture included inoculation of $10 \mathrm{~mL}$ of nutrient broth medium with a culture that was maintained on a blood agar at $4{ }^{\circ} \mathrm{C}$ using an inoculation loop. The culture was then incubated overnight at $37^{\circ} \mathrm{C}$ and $150 \mathrm{rpm}$. The next day the composites were placed in the sterile tubes with $2 \mathrm{~mL}$ of nutrient broth, which was then inoculated with $2 \mu \mathrm{L}$ of the overnight culture. The tubes were then sampled at time 0 and placed into an incubator at $37^{\circ} \mathrm{C}$ and $600 \mathrm{rpm}$ for $24-\mathrm{h}$ incubation. The samples taken at time 0 were then diluted to desirable dilutions, plated onto nutrient agar, and incubated overnight at $37^{\circ} \mathrm{C}$. The next day the colony forming units (CFUs) were counted on statistically significant plates: 30-300 (CFUs) using the standard plate counts, also known as plate count agar (PCA) method (Jorgensen, Ferraro, Jorgensen, \& Ferraro, 2009). The tubes were again sampled at time $24 \mathrm{~h}$ and the dilution and plating procedure from the previous day was repeated. The plates were incubated overnight at $37^{\circ} \mathrm{C}$. The next day the CFUs were counted again. From the CFU data obtained from time 0 and $24 \mathrm{~h}$, log of reduction of bacteria defined as follows was calculated for each experiment:

$\log$ of reduction $=\log \frac{N_{0}}{N_{t}}$

where $N_{0}$ is the number of bacteria at the beginning of the experiment, and $N_{\mathrm{t}}$ is the number of bacteria after $24 \mathrm{~h}$.

\section{Results and discussion}

\subsection{Fourier transform infrared (FTIR)}

FTIR was used to confirm that ionic liquid does not produce any chemical alterations during the dissolution of wool, hair, chicken feather, and CEL and the synthesis the [Wool + CEL], [Hair + CEL] and [Feather + CEL] composites, and to characterize the composites. Shown in Fig. 1 are the FT-IR spectra of the CEL powder, wool, hair and chicken feather as well as of the composites (80:20 wool:CEL, 80:20 hair:CEL and 80:20 feather:CEL). The spectra of the starting materials, wool (violet curve), hair (black curve) and feather (green) are very similar which is as expected as these materials contain 
keratin, and the only difference among them is a few amino acid residues and some differences in their secondary structures. All three materials exhibit several bands including two large bands at around $1520 \mathrm{~cm}^{-1}$ and $1643 \mathrm{~cm}^{-1}$ (bending of the $\mathrm{N}-\mathrm{H}$ of the amide bands), and the $1216 \mathrm{~cm}^{-1}$ band which can be attributed to the in phase combination of the $\mathrm{N}-\mathrm{H}$ bending and the $\mathrm{C}-\mathrm{N}$ stretch vibrations (amide III) (Greve, Andersen, \& Nielsen, 2008; Sowa, Wang, Schultz, Ahmed, \& Mantsch, 1995). It is noteworthy to add that the FTIR spectrum of wool does not have any band at $1745 \mathrm{~cm}^{-1}$, which is known to be due to lipid ester carbonyl vibrations (Tanabe, Okitsu, Tachibana, \& Yamauchi, 2002). It seems, therefore, that the Soxhlet extraction effectively removed all residual lipids from wool. For reference, the spectrum of CEL powder was also taken (orange curve). It exhibits several distinct different bands at around $1350 \mathrm{~cm}^{-1}$, $1147 \mathrm{~cm}^{-1}$ and $800 \mathrm{~cm}^{-1}$ which can be tentatively, assigned to the 0 $-\mathrm{H}$ bending vibration, the $\mathrm{C}-\mathrm{O}$ stretching (of the $\mathrm{C}-\mathrm{OH}$ group) and the $\mathrm{C} \_\mathrm{H}$ stretching, respectively (Duri and Tran, 2013, Harkins et al., 2014, Mututuvari and Tran, 2014, Tran, Duri and Harkins, 2013 and Tran, Duri, Delneri et al., 2013).

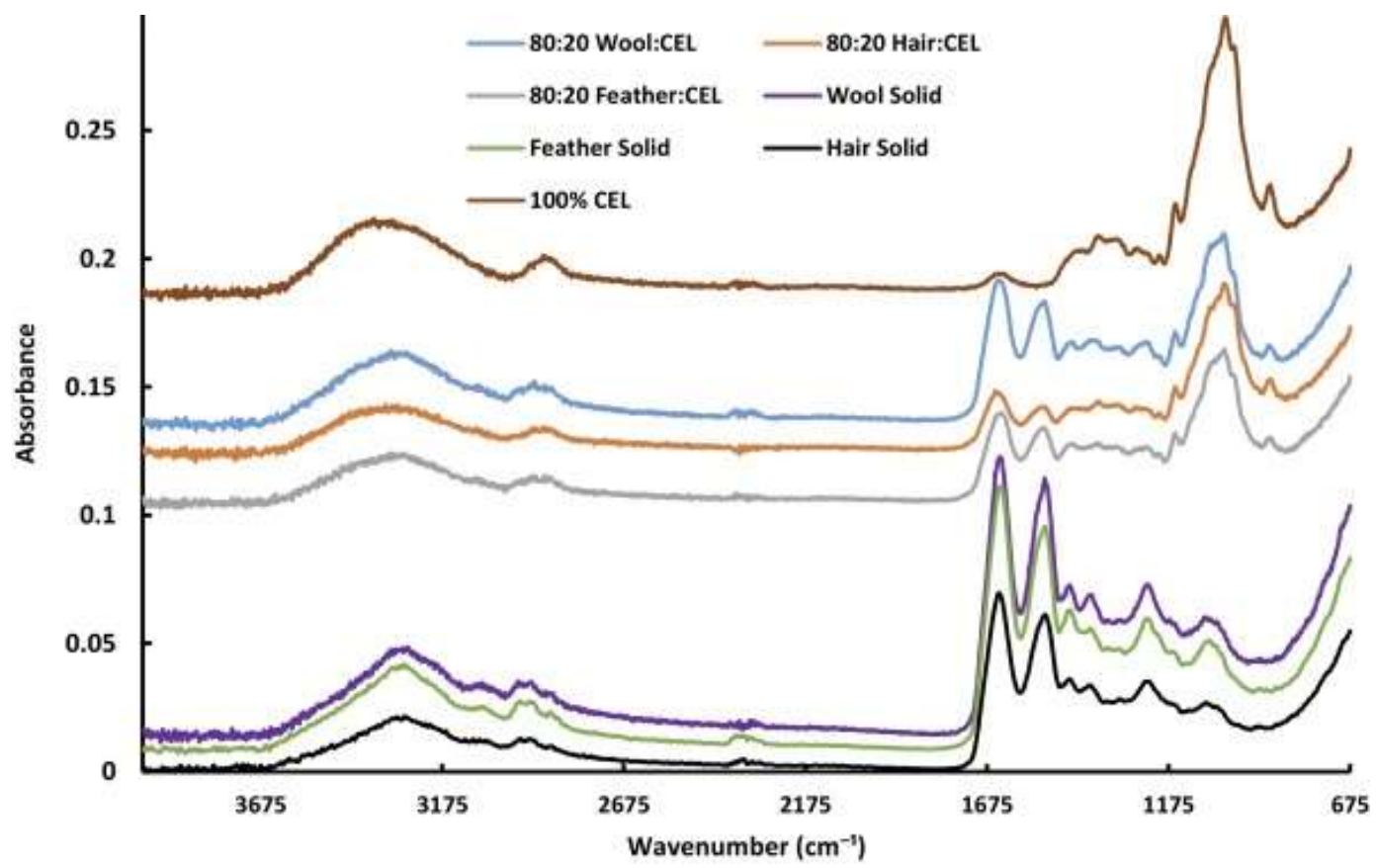

Fig. 1. FTIR spectra of materials with different compositions and concentrations; Hair (black), wool (violet), feather (green), 100\% CEL (red), 80:20 [Wool:CEL] (blue), 80:20 [Hair:CEL] (orange) and 80:20 [Feather:CEL] (light gray) (for interpretation of the references to colour in this figure legend, the reader is referred to the web version of this article).

Carbohydrate Polymers, Vol 151 (October 20, 2016): pg. 1269-1276. DOI. This article is (C) Elsevier and permission has been granted for this version to appear in e-Publications@Marquette. Elsevier does not grant permission for this article to be further copied/distributed or hosted elsewhere without the express permission from Elsevier. 
The spectra of composites between $20 \%$ CEL and $80 \%$ of either wool, hair or feather are also presented in the figure. As expected, the spectra of these composites exhibit bands characteristic of their respective components, namely, the bands at $1520 \mathrm{~cm}^{-1}, 1643 \mathrm{~cm}^{-1}$ and $1216 \mathrm{~cm}^{-1}$ from KER and the $1350 \mathrm{~cm}^{-1}, 1147 \mathrm{~cm}^{-1}$ and $800 \mathrm{~cm}^{-1}$ bands of CEL. Furthermore, the magnitude of these bands seems to correlate well with the concentration of corresponding component in the film. For example; the bands due to CEL in the composites correspond to $20 \%$ to those in the CEL powder whereas the KER bands are about $80 \%$ to those of wool, hair and feather.

\subsection{Powder $X$-ray diffraction (XRD)}

Fig. 2A shows XRD spectra for wool, hair and chicken. Wool (green curve) exhibits two bands at $2 \theta$ of about $9^{\circ}$ and $20^{\circ}$. They can be attributed to the a-helix and other structures including $\beta$-sheet and random form, respectively (Appelbaum, 2007 and McKittrick et al., 2012). As expected, hair (black curve) and feather (red curve) also have similar spectrum as that of wool. However, the relative intensity of the two bands at $9^{\circ}$ and $20^{\circ}$ for hair and feather are different from that of wool. Since the total intensity, or rather the area under these two bands are the same (i.e., $100 \%$ or total structure of the composite which includes a-helix and other structures including $\beta$-sheet and random form), the fact that the bands at $2 \theta=20^{\circ}$ for both hair and feather are of relatively higher intensity than that of wool while their a-helix bands at $9^{\circ}$ are similar to that of wool clearly indicates that the a-helix content is highest for wool followed by hair with feather has the lowest content.

Carbohydrate Polymers, Vol 151 (October 20, 2016): pg. 1269-1276. DOI. This article is (C Elsevier and permission has been granted for this version to appear in e-Publications@Marquette. Elsevier does not grant permission for this article to be further copied/distributed or hosted elsewhere without the express permission from Elsevier. 
NOT THE PUBLISHED VERSION; this is the author's final, peer-reviewed manuscript. The published version may be accessed by following the link in the citation at the bottom of the page.
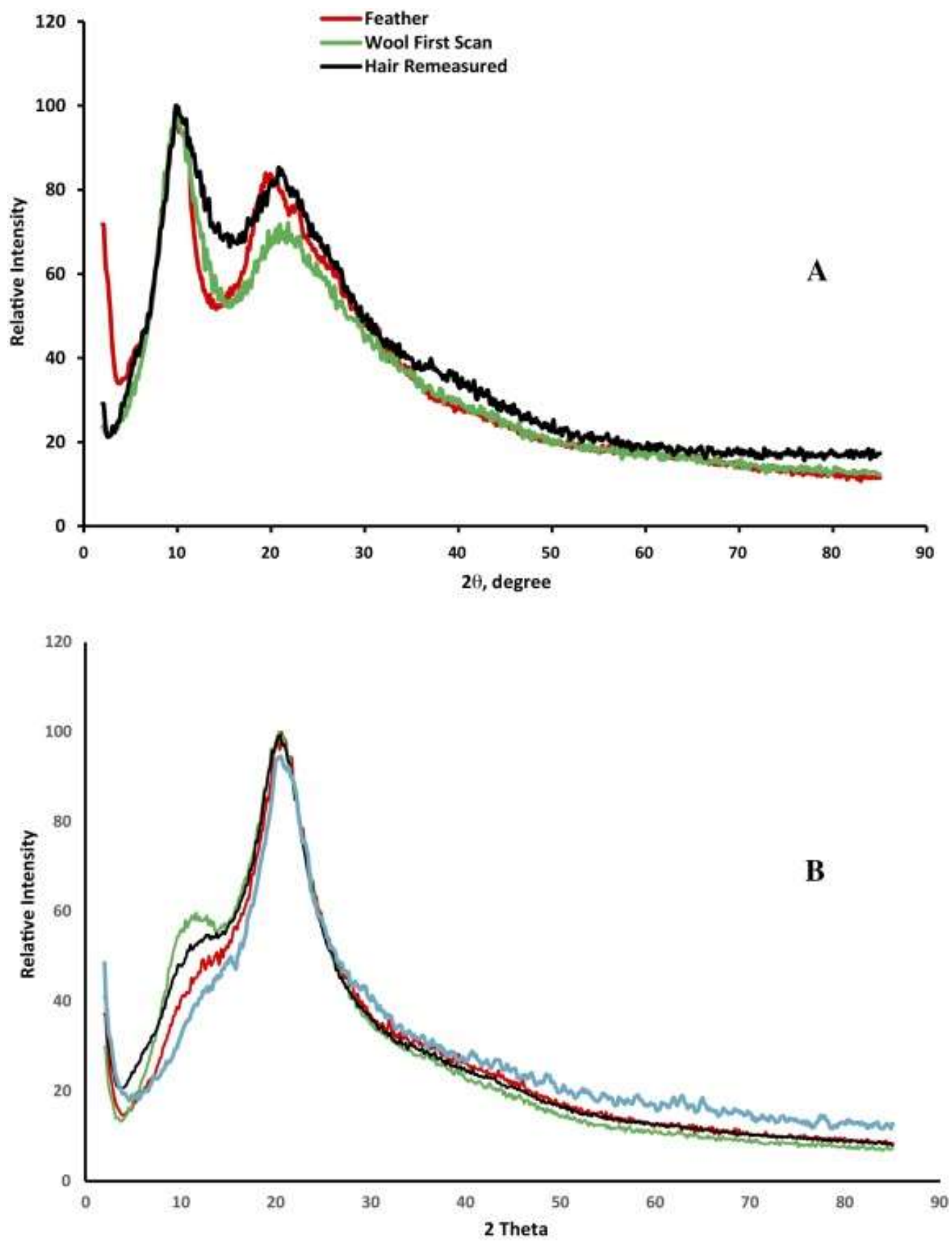

Fig. 2. X-ray diffraction spectra of (A): wool (green curve), hair (black curve) and chicken feather (red curve); and (B): 80:20 wool:CEL (green curve), 80:20 hair:CEL (black curve), 80:20 feather:CEL (red curve) and 100\% CEL (teal) composites (for interpretation of the references to colour in this figure legend, the reader is referred to the web version of this article). 
XRD spectra of $80: 20$ wool:CEL (green curve), 80:20 hair:CEL (black curve), 80:20 feather:CEL (red curve) and 100\%CEL (teal curve) composites are also presented in Fig. 2B. Different from pure wool, hair and feather, all three composites exhibit a pronounced band at around $2 \theta=20^{\circ}$ and a shoulder at $2 \theta=9^{\circ}$. In fact the spectra of all three composites are similar to the spectrum of the regenerated $100 \%$ CEL which is known to have only random structure. These results seem to indicate that adding CEL to these KER materials substantially decreases the a-helix structure while increase the $\beta$-sheet and other forms. It seems that during the dissolution with $\left[\mathrm{BMIm}^{+} \mathrm{Cl}^{-}\right]$, the inter- and intra-molecular bonds in wool, hair and feather were broken thereby destroying its secondary structure while maintaining its primary structure. During gelation, regeneration from water and drying, these interactions were reestablished thereby partially reforming some of the original secondary structure. However, in the presence of CEL the chains are maintained in the extended form thereby hindering a significant reformation of the a-helix. Consequently, the composites formed may adopt structures with relatively lower content of a-helix and higher $\beta$-sheet content.

\subsection{Scanning electron microscope (SEM)}

Fig. 3 shows SEM images of the surfaces and cross sections of regenerated $100 \%$ CEL, $100 \%$ wool, [CEL + Wool], [CEL + Hair] and [CEL + Feather] composites with different compositions. While images for $100 \%$ CEL exhibit smooth and homogeneous morphologies without any pores, the images of $100 \%$ wool exhibit a rough and porous structure with a three dimensional interconnection throughout the film surface. This porous structure seems to reflect the physical properties of KER films, namely the brittleness of the regenerated $100 \%$ wool film, and the fact that it was not possible for us to regenerate $100 \%$ hair and $100 \%$ feather films as they were found to be too brittle. CEL was added to wool, hair and feather to improve mechanical property of the composites. From both surface and cross sections SEM images of [wool + CEL], [feather + CEL] and [hair + CEL] at various compositions (90:10, 80:20 and 65:35) it is clear that CEL forms homogenous composites with all three proteins and at all compositions. As expected, adding KER to the proteins introduces roughness to the composites. Moreover, the microstructures of the

Carbohydrate Polymers, Vol 151 (October 20, 2016): pg. 1269-1276. DOI. This article is (C Elsevier and permission has been granted for this version to appear in e-Publications@Marquette. Elsevier does not grant permission for this article to be further copied/distributed or hosted elsewhere without the express permission from Elsevier. 
composites are dependent on the source of KER (i.e., wool, hair or feather) are noticeably different from one anthother. For example, 90:10 wool:CEL composite seems to be somewhat rougher than $100 \%$ CEL and $100 \%$ wool. It is, however, relatively finer than the corresponding 90:10 hair:CEL composite. On the other hand, the 90:10 feather:CEL composite exhibits highest degree of roughness. Again these results seem to correlate with results presented above on the conformation of the proteins, namely, because wool has the higheset a-helix content, when mix with CEL, it still can retain some of its structure, thereby producing composites with relatively finer structure than those of hair and feather. Conversely, feather which has the lowest a-helix content, does not seem to be able to mix well with CEL. As a consequence, the resultant composites has the highest degree of roughness compared to corresponding wool and hair composites. Since CEL has distinctly different structure from wool, hair and feather, increasing concentration of CEL in the composite from $10 \%$ to $20 \%$ and $35 \%$ leads to increase in the roughness of the composites. Again, as expected, for the same composition, the roughness is highest for the feather: CEL composite followed by hair:CEL composite with the wool:CEL composite has the lowest roughness structure. 
NOT THE PUBLISHED VERSION; this is the author's final, peer-reviewed manuscript. The published version may be accessed by following the link in the citation at the bottom of the page.

\section{Surface Images}

$100 \%$ CEL

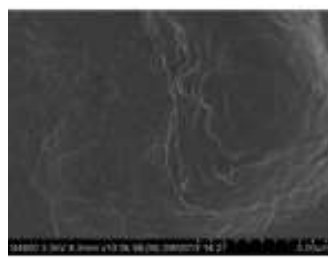

$100 \%$ Wool

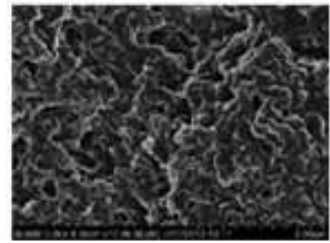

80:20 Wool:CEL

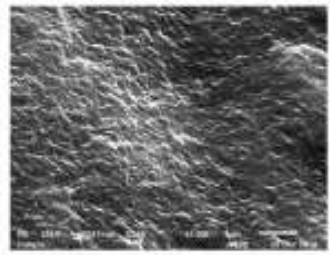

65:35 Wool:CEL.

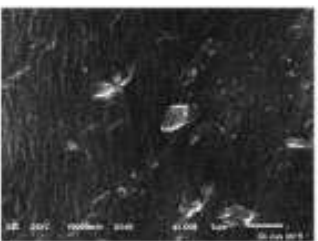

80:20 Feather:CEL

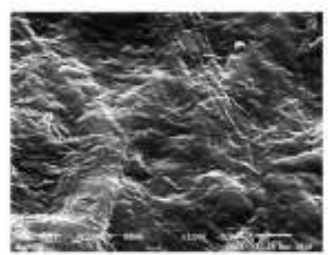

65:35 feather:CEL

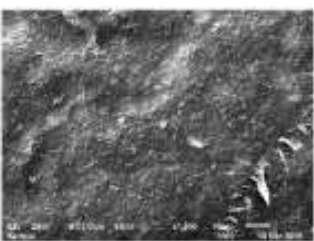

80:20 Hair:CEL

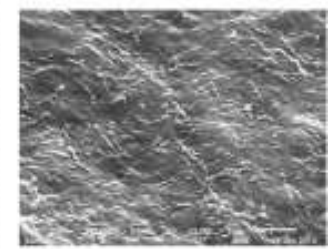

65:35 Hair:CEL

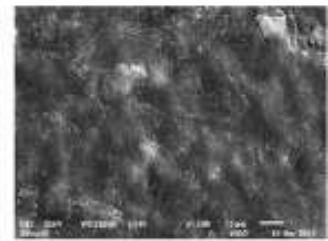

\section{Cross Section Images}

$100 \%$ CEL

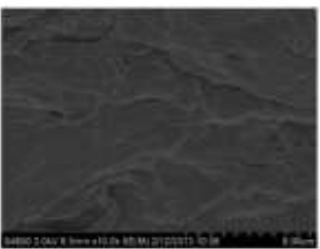

$100 \%$ Wool

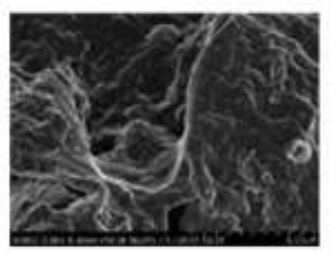

90:10 Wool:CEL

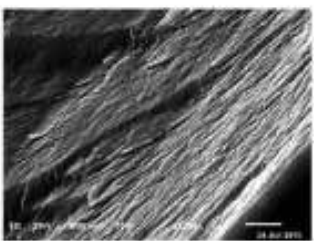

80:20 Wool:CEL

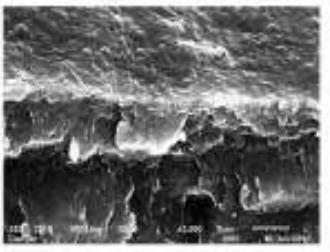

65:35 Wool:CEL

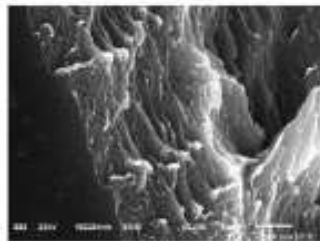

90:10 feather:CEL

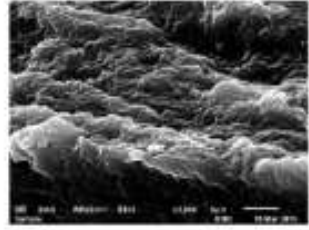

80:20 Feather:CEL

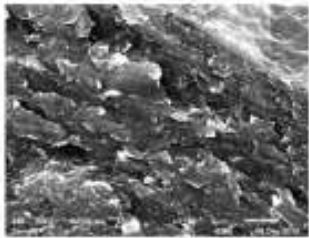

65:35 feather:CEL

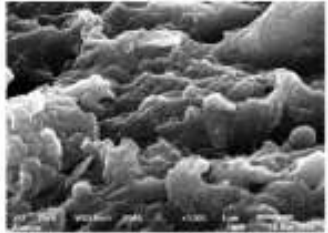

90: 10 Hair:CEL

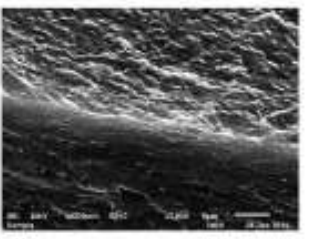

80:20 Hair:CEL

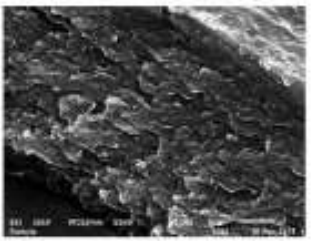

65:35 Hair:CEL

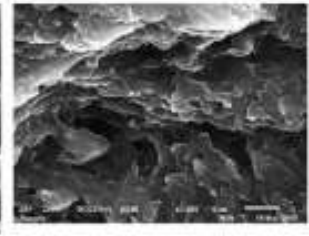

Fig. 3. Surface SEM images (top two rows) and cross-sectional images (last three rows) of CEL, Wool, [Wool + CEL], [Hair:CEL] and [Feather:CEL] composites with different compositions. 
NOT THE PUBLISHED VERSION; this is the author's final, peer-reviewed manuscript. The published version may be accessed by following the link in the citation at the bottom of the page.

\subsection{Mechanical properties}

It is known that KER can encapsulate and control release of drugs (Cilurzo et al., 2013). However, its poor mechanical properties continue to hamper its potential applications. For example, as previously reported and also observed in this study, regenerated KER film was found to be too brittle to be reasonably used in any application (Hill et al., 2010, Sando et al., 2010, Vasconcelos and Cavaco-Paulo, 2013 and Verma et al., 2008). Since CEL is known to possess superior mechanical strength, it is possible enhance the mechanical property of KER-based composite by adding CEL into it. Accordingly, CEL was added to either wool, hair or feather to prepare $[$ Wool + CEL $]$, [Hair + CEL] and [Feather + CEL] composites with different concentrations. In Fig. 4, the tensile strength of the composites was plotted as a function of cellulose content. As expected, adding CEL to either wool, hair or feather substantially increases the tensile strength of the composites. For example, the tensile strength of 80:20 Feather: CEL composite (blue dashed-dotted curve) increased from 19.08 MPa to $45.93 \mathrm{MPs}$ or $\sim 2.5 \mathrm{X}$ when CEL loading was increased from $20 \%$ to $35 \%$. Up to $5 X$ increase was observed when CEL loading was increased to $60 \%$ (i.e., $94.66 \mathrm{MPa}$ ). The same effect was also observed for [Wool + CEL] composites (green dashed curve) and [Hair + CEL] composites (red dotted curve) as well. Interestingly, enhancement effect induced by CEL is highest for [Feather + CEL] composites and lowest for [Wool + CEL] composites. This may be due to the effect CEL has on the secondary structure of KER in feather, hair and wool. As described in previous section, X-ray diffraction results indicate that for the same CEL loading, the a-helix content is highest for [wool + CEL] composites followed by [Hair + CEL] composites with [Feather + CEL] composites have the lowest content. That is, the interactions between CEL and feather is strongest whereas the weakest is between CEL and wool. KER can, therefore retain relatively less secondary structure or less a-helix content in the [Feather + CEL] composites compared to [Wool + CEL] and [Hair + CEL] composites. Since CEL can interact stronger with feather, it would impart more mechanical strength to feather than to wool or hair. Consequently, [Feather + CEL] composites have stronger mechanical strength than [Hair + CEL], and [Wool + CEL] composites have the weakest mechanical strength.

Carbohydrate Polymers, Vol 151 (October 20, 2016): pg. 1269-1276. DOI. This article is (C Elsevier and permission has been granted for this version to appear in e-Publications@Marquette. Elsevier does not grant permission for this article to be further copied/distributed or hosted elsewhere without the express permission from Elsevier. 


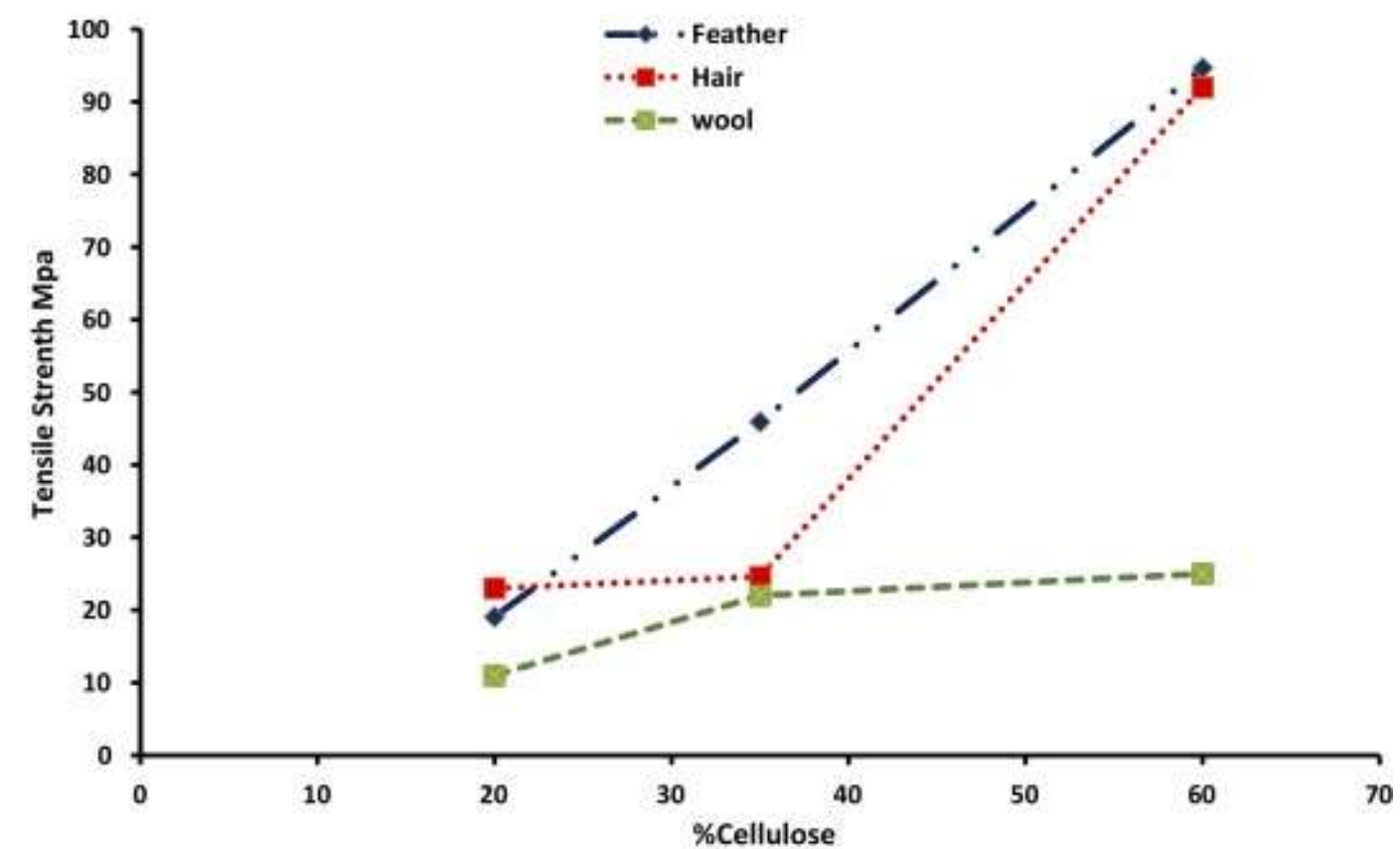

Fig. 4. Plots of tensile strength as a function of\%CEL in [CEL + Hair] composites (red dotted curve), [CEL + Feather] composites (blue dashed-dotted curve) and [CEL + wool] composites (green dashed curve) (for interpretation of the references to colour in this figure legend, the reader is referred to the web version of this article).

\subsection{Antibacterial assays}

Experiments were then to carry out to determine the composites have any effect on selected gram negative ( $E$. coli, $P$. aeruginosa) and gram positive bacteria ( $S$. aureus, MRSA, VRE). Different types of composites ([Hair + CEL], [Feather + CEL] and [Wool + CEL]) with different concentrations (40:60,65:35, 75:25 and 80:20 of either wool, hair or feather and CEL) were evaluated by growing the bacteria in the presence of the composites for $24 \mathrm{~h}$ and then plated out onto nutrient agar plates. The number of colonies formed after overnight incubation was compared to a standard growth control. Results obtained, plotted as Microbial Log Removal are shown in Fig. 5A-D for E. coli, S. aureus, MRSA and VRE. It is evident from Fig. 5A, B and D, that within experimental errors, all three composites ([CEL + Hair], $[\mathrm{CEL}+$ Feather] and [CEL + wool]) did not inhibit any observable antimicrobial activity against $E$. coli, S. aureus and VRE. Interestingly, all three composites did show some antibacterial activity against MRSA, and the antimicrobial activity is dependent not only the on the type of the protein but also on its relative concentration as well. For examples, the 65:35 Wool:CEL exhibited very small if any effect 
whereas the 65:35 Feather:CEL did show substantially strong antimicrobial effect against MRSA. Hair: CEL composites seem to have relatively stronger effect than wool but weaker than feather, namely, at $80 \%$ protein content, the [Hair:CEL] exhibit somewhat stronger than that by $80: 20$ Wool;CEL but still much weaker than that of $80: 20$ Feather:CEL. Together, the results seem to indicate that similar to our previous work on the [CEL + chitosan] composites, CEL does not have any antimicrobial activity at all ( Harkins et al., 2014 and Tran, Duri and Harkins, 2013). The antibacterial property is due only to protein but also to the specific type of the keratin as well. That is, the bactericidal effect is strongest for feather followed by hair and the weakest is for wool. Taken together the antimicrobial effect and the secondary structure results presented in the previous section, suggest that feather with its highest content of random structure (i.e., lowest a-helix content) can readily interact with MRSA which enable it to exhibit strongest antimicrobial activity. Conversely, wool with its highest a-helix content, has relatively more defined structure which somewhat restricts its ability to interact with bacteria. As a consequence, it has the lowest antimicrobial activity. Hair with its structure in the middle of feather and wool, has the middle range of antimicrobial effect.
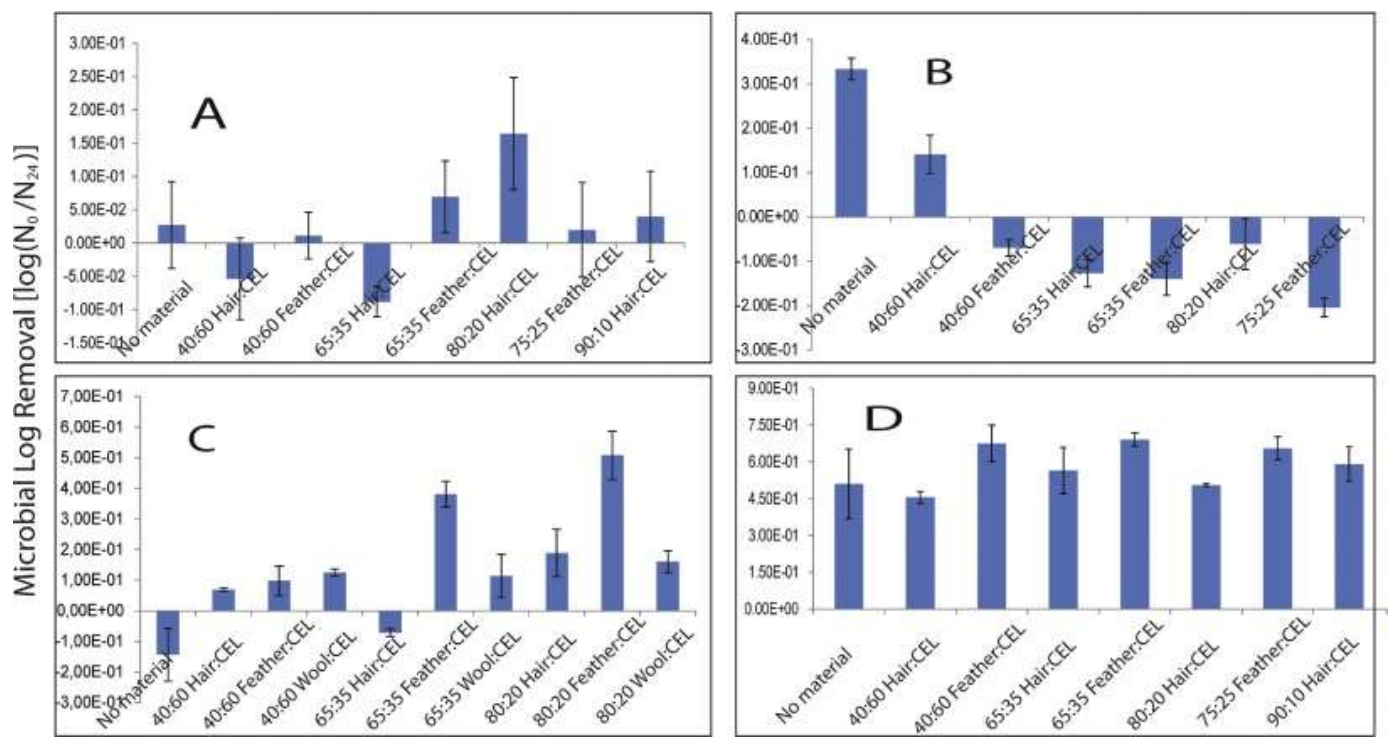

Fig. 5. Log of reduction in number of bacteria (A): E. coli, (B): S. aureus, (C): MRSA, (D): VRE after exposure to [CEL + Hair], [CEL + Feather] and [CEL + Wool] composites for $24 \mathrm{~h}$ compared to a control (no composite). Each bar represents an average of 3 measurements together with associated standard deviations.

Carbohydrate Polymers, Vol 151 (October 20, 2016): pg. 1269-1276. DOI. This article is (C) Elsevier and permission has been granted for this version to appear in e-Publications@Marquette. Elsevier does not grant permission for this article to be further copied/distributed or hosted elsewhere without the express permission from Elsevier. 
NOT THE PUBLISHED VERSION; this is the author's final, peer-reviewed manuscript. The published version may be accessed by following the link in the citation at the bottom of the page.

\section{Conclusions}

In summary, we have shown that composites between CEL and keratin from three different sources (wool, hair and feather) were successfully and readily synthesized in a simple one-step process in which $\left[\mathrm{BMIm}^{+} \mathrm{Cl}^{-}\right]$, an ionic liquid, was used as the sole solvent. The method is green and recyclable because majority of $\left[\mathrm{BMIm}^{+} \mathrm{Cl}^{-}\right]$used was recovered for reuse. Results of spectroscopy (FTIR, XRD) and imaging (SEM) measurements confirm that CEL and KER (from all three sources: wool, hair and chicken feather) remain chemically intact and homogeneously distributed in the composites. KER also retains some of its secondary structure in the composites. Interestingly, the minor differences in the compositions of KER in wool, hair and feather magnifies into pronounced differences in the structure of wool, hair and feather and their corresponding composites with wool has the highest content of a-helix, followed by hair and feather has the lowest content. These results correlate well with SEM results and properties (mechanical and antimicrobial properties) of the composites. Specifically, adding CEL into KER substantially improves mechanical strength of all three composites [CEL + wool], [CEL + hair] and $[C E L+$ feather]. Since mechanical strength is due to CEL, and CEL has only random structure, [CEL + feather] has, expectedly, the strongest mechanical property because feather has the lowest content of a-helix. Conversely, [CEL + wool] composite has the weakest mechanical strength because wool has the highest a-helix content. All three composites, [Feather + CEL], [Hair + CEL] and [Wool + CEL] were found to exhibit antibacterial activity against MRSA. The antibacterial property is due not to CEL but rather to the protein and is strongly dependent on the type of the keratin. That is, the bactericidal effect is strongest for feather followed by hair and the weakest is for wool. For example, up to $1.5 \mathrm{log}$ and $1.75 \mathrm{logs}$ of reduction of MRSA growth were observed in the presence of 80:20 Wool:CEL and Hair:CEL composites, respectively. Remarkably, the Feather:CEL composite with the same composition exhibits up to 5 log of reduction for growth of MRSA. These results together with our previous finding that [CEL + KER] composites can be used for drug delivery as the kinetics of the release can be controlled by adjusting the concentration of wool keratin in the composite (Mututuvari \& Tran, 2014), clearly indicate that the composites can be used as dressing to treat ulcerous wounds.

Carbohydrate Polymers, Vol 151 (October 20, 2016): pg. 1269-1276. DOI. This article is (c) Elsevier and permission has been granted for this version to appear in e-Publications@Marquette. Elsevier does not grant permission for this article to be further copied/distributed or hosted elsewhere without the express permission from Elsevier. 
Moreover, the research reported here also has profound beneficial effect on the environment as it provide a facile, green and recyclable method to readily convert otherwise polluted substances such as wool (waste product from textile industry), hair and chicken feather into biocompatible and useful materials for water purification and wound healing.

\section{Conflict of interest}

The authors declare no financial interest.

\section{Acknowledgments}

The authors are grateful to Emily Lentz for supplying some of the composites, Prof. Raymond Fournelle for his competent assistance to measure SEM, Moven Mututuvari and James Makuvaza for their assistance. One of us (FP) thanks the Fulbright Foundation for a fellowship support to spend time doing research at Marquette University. Research reported in this publication was supported by the National Institute of General Medical Sciences of the National Institutes of Health under Award number R15GM099033.

\section{References}

Appelbaum, 2007. P.C. Appelbaum. Microbiology of antibiotic resistance in Staphylococcus aureus. Clinical Infectious Diseases, 45 (Suppl. 3) (2007), pp. S165-S170

Chen et al., 2014. J. Chen, K. Vongsanga, X. Wang, N. Byrne. What happens during natural protein fibre dissolution in ionic liquids. Material, 7 (2014), pp. 6158-6168

Cilurzo et al., 2013. C. Cilurzo, F. Selmin, A. Aluigi, S. Bellosta. Regenerated keratin proteins as potential biomaterial for drug delivery. Polymers for Advance Technologies, 24 (2013), pp. 1025-1028

Cui et al., 2013. L. Cui, J. Gong, X. Fan, P. Wang, Q. Wang, Y. Qiu. Trans glutaminase-modified wool keratin film and its potential application in tissue engineering. Engineering in Life Sciences, 13 (2013), pp. 149155

Dullaart and Mousquès, 2012. Keratin: structure, properties, and applications. R. Dullaart, J. Mousquès (Eds.)Nova Science Publishers, Hauppauge, N.Y (2012)

Duri and Tran, 2013. S. Duri, C.D. Tran. Supramolecular composite materials from cellulose, chitosan and cyclodextrin: facile preparation and their

Carbohydrate Polymers, Vol 151 (October 20, 2016): pg. 1269-1276. DOI. This article is (C) Elsevier and permission has been granted for this version to appear in e-Publications@Marquette. Elsevier does not grant permission for this article to be further copied/distributed or hosted elsewhere without the express permission from Elsevier. 
selective inclusion complex formation with endocrine disruptors. Langmuir, 29 (2013), pp. 5037-5049

Duri et al., 2010. S. Duri, S. Majoni, J.M. Hossenlopp, C.D. Tran. Determination of chemical homogeneity of fire retardant polymeric nanocomposite materials by near-infrared multispectral imaging microscopy. Analytical Letters, 43 (2010), pp. 1780-1789

Greve et al., 2008. T.M. Greve, K.B. Andersen, O.F. Nielsen. Penetration mechanism of dimethyl sulfoxide in human and pig ear skin: an ATRFTIR and near-FT Raman Spectroscopic in vivo and in vitro study. Spectroscopy, 22 (2008), pp. 405-417

Harkins et al., 2014. A.L. Harkins, S. Duri, L.C. Kloth, C.D. Tran. Chitosancellulose composite for wound dressing material. Part 2. Antimicrobial activity, blood absorption ability, and biocompatibility. Journal of Biomedical Materials Research Part B, 102 (2014), pp. 1199-1206 Haverhals et al., 2012. L.M. Haverhals, W.M. Reichert, N. Nazare, M. Zammarano, J.W. Gilman, H.C. De Long, et al. Ionic liquid facilitated introduction of functional materials into biopolymer polymer substrates, in molten salts and ionic liquids 18. ECS Transactions, Vol. 50 (11) (2012), pp. 631-640

Hill et al., 2010. P. Hill, H. Brantley, M. Van Dyke. Some properties of keratin biomaterials: kerateines. Biomaterials, 1 (2010), pp. 585-593

Jorgensen et al., 2009. J.H. Jorgensen, M.J. Ferraro, J.H. Jorgensen, M.J. Ferraro. Antimicrobial susceptibility testing: a review of general principles and contemporary practices. Clinical Infectious Diseases, 49 (11) (2009), pp. 1749-1755

Justin et al., 2011. M. Justin, M.D. Saul, R. Ellenburg, C. de Guzman, M. Van Dyke. Keratin hydrogels support the sustained release of bioactive ciprofloxacin. Journal of Biomedical Materials Research Part A, 98 (A) (2011), pp. 544-553

McKittrick et al., 2012. J. McKittrick, P.Y. Chen, S.G. Bodde, W. Yang, E.E. Novitskaya, M.A. Meyers. The structure, functions, and mechanical properties of keratin. JOM, 64 (2012), pp. 449-468

Mututuvari and Tran, 2014. T.M. Mututuvari, C.D. Tran. Synergistic adsorption of heavy metal ions and organic pollutants by polysaccharide supramolecular composite materials from cellulose, chitosan and crown ether. Journal of Hazardous Materials, 264 (2014), pp. 449-459

Mututuvari et al., 2013. T.M. Mututuvari, A.L. Harkins, C.D. Tran. Facile synthesis, characterization and antimicrobial activity of celluloseChitosan-Hydroxy apatite composite material, a potential material for bone tissue engineering. Journal of Biomedical Materials Research Part A, 101 (11) (2013), pp. 3266-3277

Carbohydrate Polymers, Vol 151 (October 20, 2016): pg. 1269-1276. DOI. This article is @ Elsevier and permission has been granted for this version to appear in e-Publications@Marquette. Elsevier does not grant permission for this article to be further copied/distributed or hosted elsewhere without the express permission from Elsevier 
Sando et al., 2010. L. Sando, M. Kim, M.L. Colgrave, J.A. Ramshaw, J.A. Werkmeister, C.M. Elvin. Photochemical crosslinking of soluble wool keratins produces a mechanically stable biomaterial that supports cell adhesion and proliferation. Journal of Biomedical Materials Research Part A, 95 (2010), pp. 901-911

Sowa et al., 1995. M.G. Sowa, J. Wang, C.P. Schultz, M.K. Ahmed, H.H. Mantsch. Infrared spectroscopic investigation of in vivo and ex vivo human nails. Vibrational Spectroscopy, 10 (1995), pp. 49-56

Tanabe et al., 2002. T. Tanabe, N. Okitsu, A. Tachibana, K. Yamauchi. Preparation and characterization of keratin-chitosan composite film. Biomaterials, 23 (2002), pp. 817-825

Tran and Mututuvari, 2015. C.D. Tran, T.M. Mututuvari. Cellulose, chitosan and keratin composite materials controlled drug release. Langmuir, 31 (2015), pp. 1516-1526

Tran, Duri and Harkins, 2013. C.D. Tran, S. Duri, A.L. Harkins. Recyclable synthesis, characterization, and antimicrobial activity of chitosan-based polysaccharide composite materials. Journal of Biomedical Materials Research Part A, 101 (2013), pp. 2248-2257

Tran, Duri, Delneri et al., 2013. C.D. Tran, S. Duri, A. Delneri, M. Franko. Chitosan-cellulose composite materials: preparation, characterization and application for removal of microcystin. Journal of Hazardous Materials, 252 (2013), pp. 355-366

Vasconcelos and Cavaco-Paulo, 2013. A. Vasconcelos, A. Cavaco-Paulo. The use of keratin in biomedical applications. Current Drug Targets, 14 (2013), pp. 612-619

Verma et al., 2008. V. Verma, P. Verma, A.R. Ray. Preparation of scaffolds from human hair proteins for tissue-engineering applications.

Biomedical Materials, 3 (2008), p. 2500

Vilaplana et al., 2010. F. Vilaplana, E. Stroemberg, S. Karlsson. Environmental and resource aspects of sustainable biocomposites. Polymer Degradation and Stability, 95 (11) (2010), pp. 2147-2161

Xie et al., 2005. H. Xie, S. Li, S. Zhang. Ionic liquids as novel solvents for the dissolution and blending of wool keratin fibers. Green Chemistry, 7 (2005), pp. 606-608

Corresponding author: Mladen Franko: Permanent address: Laboratory for environment research, University of Nova Gorica, Vipavska 13, 5000 Nova Gorica, Slovenia.

Carbohydrate Polymers, Vol 151 (October 20, 2016): pg. 1269-1276. DOI. This article is (C) Elsevier and permission has been granted for this version to appear in e-Publications@Marquette. Elsevier does not grant permission for this article to be further copied/distributed or hosted elsewhere without the express permission from Elsevier. 